\title{
Occupational Risk Factors for Seropositive Leptospirosis among Town Service Workers in Northeastern Malaysia
}

Mohd Nazri Shafeil', Mohamad Azfar Zainuddin², Nor Azwany Yaacobํ, Zahiruddin Wan Mohammad', Nabilah Awang ${ }^{3}$, Siti Asma' Hassan³, Fairuz Amran ${ }^{4}$, Aziah Daud $^{1 *}$

\author{
1 Department of Community Medicine, \\ School of Medical Sciences, \\ Universiti Sains Malaysia, Kubang Kerian, \\ Kelantan, Malaysia \\ ${ }^{2}$ District Health Office Penang, \\ Ministry of Health, Penang, Malaysia \\ ${ }^{3}$ Department of Medical Microbiology \& \\ Parasitology, School of Medical Sciences, \\ Universiti Sains Malaysia, Kubang Kerian, \\ Kelantan, Malaysia \\ ${ }^{4}$ Institute for Medical Research (IMR), \\ Kuala Lumpur, Malaysia
}

\section{*Corresponding author's email: aziahkb@usm.my}

Received: 9 June 2021

Accepted: 7 September 2021

DOI: https://doi.org/10.51200/bjms.vi.3139

Keywords: leptospirosis, microscopic agglutination test, occupational hazards

\section{ABSTRACT}

Leptospirosis is speculated to be one of the most prevalent re-emerging zoonotic diseases to date, and town service workers are continuously exposed to occupational hazards that may increase their risk of infection. This study aimed to determine the occupational risk factors for leptospirosis among town service workers in northeastern Malaysia. A cross-sectional study was conducted among town service workers from four municipal councils. All sera samples were tested for the presence of antileptospiral antibodies using an enzyme-linked immunosorbent assay (ELISA) followed by a microscopic agglutination test (MAT). We found that 82 serum samples from 321 respondents were positive in the MAT (seroprevalence rate of $\mathbf{2 5 . 5 \% ) . ~ M u l t i p l e ~ l o g i s t i c ~ r e g r e s s i o n ~ a n a l y s i s ~}$ identified overtime work (adj. OR 2.13; 95\% Cl $1.19,3.84)$, contact with animals while working (adj. OR 2.09; 95\% Cl 1.06, 4.11), sighting of rats at the worksite (adj. OR 2.17; 95\% Cl 1.11, 4.25) and living less than $200 \mathrm{~m}$ from a river (adj. OR 1.84; $95 \% \mathrm{Cl} 1.03,3.28$ ) as risk factors for leptospiral infection. Whereas age (adj. OR 0.95; $95 \% \mathrm{Cl} 0.93,0.98)$, wearing boots while working (adj. OR 0.44; 95\% Cl 0.25, 0.80) and washing hands with soap after work (adj. OR $0.20 ; 95 \% \mathrm{Cl}$ $0.10,0.42$ ) were recognised as protective factors. In conclusion, an association was observed between leptospirosis seropositivity among town service workers and the occupational factors. Prevention and control strategies for leptospirosis will require more focus on curbing the possible sources of leptospirosis transmission and maintaining safe work practices in high-risk working environments. 


\section{INTRODUCTION}

Human leptospirosis is a re-emerging endemic infectious disease in Malaysia (Thayaparan et al., 2013) and it is well known as an occupational disease for many groups of workers who are involved in outdoor work or work that requires contact with animals (Cointreau, 2006; Spies, 2010). Areas such as the garbage disposal sites of public authorities, open dumps and illegal dumping sites with uncollected solid waste contribute to a favourable environment for rodents to breed and feed while spreading leptospirosis via excreted urine (Cointreau, 2006; Spies, 2010).

Leptospirosis is still under-reported due to the wide range of clinical presentations associated with acute leptospiral infection (Levett, 2001; Victoriano et al., 2009). In Malaysia, Ministry of Health data showed that from 2004 to 2009, the prevalence of leptospirosis increased dramatically and that the case fatality rates (CFR) varied from $1.8 \%$ to $7.6 \%$, with an average of $4.44 \%$ (Ministry of Health, 2011; Thayaparan et al., 2013).

The incubation period for leptospirosis is usually between 5 and 14 days, with a range of 2 to 30 days. In humans, it can cause a variety of symptoms, from asymptomatic to mild (influenza-like symptoms) to severe (Weils' syndrome) clinical manifestations. Delay in seeking treatment leads to complications such as renal failure, meningitis (inflammation of the membrane around the brain and spinal cord), liver damage, respiratory distress and widespread haemorrhage (Dircio Montes Sergio et al., 2012).

Humans are exposed to leptospirosis via occupational, recreational or environmental factors (Levett, 2001). High-risk occupations, such as town service workers, paddy planters, army personnel and health care workers, are more vulnerable to leptospiral infection due to the presence of occupational and environmental determinants for human leptospirosis in the workplace (Mohd Ridzuan et al., 2016; Sulong et al., 2011).

There are four job categories for town service workers: garbage collector, town cleaner, landscaper and lorry driver/mechanic. Garbage collectors collect garbage from containers or waste bins located in residential, commercial and industrial areas before dumping the waste material onto a lorry (truck) for disposal at landfills. Town cleaners' duties include sweeping, collecting and removing litter, detritus and leaves from public spaces (i.e., roads, pavements, drains, wet markets and public precincts). Landscapers perform a range of duties, including transporting, planting, mulching, fertilizing and watering vegetation. They also cut and trim grass via manual labour or the use of power-operated equipment. Lorry drivers drive the garbage collection lorries from the collection sites to the landfill sites, and sometimes they assist garbage collectors in performing their job. Whereas a lorry mechanic's job includes maintenance (including washing) and repair of garbage collection lorries.

Town service workers are susceptible to leptospirosis due to their substantial involvement in every step of the waste management process. In fact, a countrywide study conducted in Denmark found that infectious disease and injury risks for solid waste workers are six times higher than those of control baseline populations (Cointreau, 2006).

Leptospirosis is preventable if appropriate measures are taken, especially for modifiable risk factors. Intervention among high-risk groups is one of many preventive measures that could be taken to control this disease (Zavitsanou \& Babatsikou, 2008). Thus, this study was conducted to determine the occupational factors for leptospirosis among town service workers in northeastern Malaysia. 


\section{MATERIALS AND METHODS}

\section{Study Design and Population}

A cross-sectional study was performed in four districts in northeastern Malaysia involving 321 town service workers from the Municipal Council and three District Councils. The Municipal Council provides public services within its area of jurisdiction, which is $116 \mathrm{~km}^{2}$, whereas each District Council provides public services in an operational area of about $50 \mathrm{~km}^{2}$.

The sample size was calculated based on the $24.7 \%$ seropositivity for leptospirosis among town service workers (Sulong et al., 2011) at a 95\% confidence interval (Cl). After considering a dropout rate of $20 \%$, the estimated sample size required for the study was calculated to be 346 . The sampling frame was based on the list of town service workers provided by the Municipal Council and three District Councils (denoted District A, District B and District $C$ ) who fulfilled the study criteria. It included workers in the four job categories previously mentioned who had been working in the department for more than six months. Office workers and workers who were absent or on leave during the study period were excluded from the study. Proportionate sampling was conducted to determine the number of respondents that needed to be selected from each district. Simple random sampling was used to select respondents from the list.

\section{Blood Samples and Serologic Tests}

A venous blood sample $(5 \mathrm{~mL})$ was obtained from each respondent and the serum was separated and stored at $-20^{\circ} \mathrm{C}$. All sera samples were tested for the presence of antileptospiral antibodies using an enzyme-linked immunosorbent assay (ELISA) and microscopic agglutination test (MAT) following standard methods (WHO, 2007).

Live Leptospira cell suspensions were added to serially diluted serum samples in microtitre plates and incubated at $30^{\circ} \mathrm{C}$ for 2 h. Agglutination was examined using dark field microscopy at a magnification of $\times 100$. Agglutination was considered to be positive agglutinations when the approximate number of free leptospires was $<50 \%$ than the number of leptospires in the control wells. The titre result was taken as the last dilution that showed $<50 \%$ of free leptospires compared to control wells. A seropositive leptospirosis respondent was defined as a person who had a MAT titre of $1 \geq 100$ (Plank \& Dean, 2000).

\section{RESULTS}

Of the 346 workers who were eligible for this study, 321 participated, resulting in a response rate of $92.8 \%$. All respondents were of Malay ethnicity. The mean age was 40.6 (10.28) years and the mean duration of employment was 12.1 (9.62) years. Table 1 shows the sociodemographic characteristics of the town service workers. Among the 321 respondents, 82 serum samples returned a positive MAT result, giving a leptospirosis seroprevalence rate of $25.5 \%$. 
Borneo Journal of Medical Sciences 16 (1) January, 2022: $31-42$

Table 1 Sociodemographic characteristics of town service workers $(n=321)$

\begin{tabular}{|c|c|c|}
\hline Variable & $\begin{array}{r}\text { Frequency } \\
(\%)\end{array}$ & Mean (SD) \\
\hline Age (year) & & $40.6(10.28)$ \\
\hline \multicolumn{3}{|l|}{ Gender } \\
\hline Male & 309 (96.3) & \\
\hline Female & $12(3.7)$ & \\
\hline \multicolumn{3}{|l|}{ Marital status } \\
\hline Married & $268(83.5)$ & \\
\hline Single & $44(13.7)$ & \\
\hline Widower & $9(2.8)$ & \\
\hline Number of children & & $3.7(2.49)$ \\
\hline Monthly income (RM) & & $\begin{array}{l}1198.14 \\
(419.35) \\
\end{array}$ \\
\hline \multicolumn{3}{|l|}{ Education level } \\
\hline No formal education & $4(1.2)$ & \\
\hline Primary school & 64 (19.9) & \\
\hline $\begin{array}{l}\text { Lower secondary } \\
\text { school }\end{array}$ & $\begin{array}{c}88(27.4) \\
151(47.0)\end{array}$ & \\
\hline $\begin{array}{l}\text { Upper secondary } \\
\text { school } \\
\text { Form } 6 \text { / Diploma }\end{array}$ & $14(4.4)$ & \\
\hline
\end{tabular}

\begin{tabular}{|l|r|r|}
\hline Town council & \\
Municipal Council & $183(57.0)$ & $48(15.0)$ \\
District A & $49(15.3)$ & \\
District B & $41(12.8)$ & \\
District C & $157(48.9)$ & \\
\hline Job category & $71(22.1)$ & \\
Town cleaner & $56(17.4)$ & \\
Lorry driver/ & $37(11.5)$ & \\
mechanic & \\
Landscaper & \\
Garbage collector & \\
\hline
\end{tabular}

Table 2 shows that three sociodemographic, nine occupational and three environmental and household factors were associated with leptospirosis. No recreational activities were associated with leptospirosis seropositivity. Moderate knowledge and unsatisfactory practices were associated with an increased risk of leptospiral infection.

Table 2 Univariable analysis of associated factors for leptospirosis among 321 town service workers in northeastern state using simple logistic regression

\begin{tabular}{|c|c|c|c|c|c|}
\hline \multirow[t]{2}{*}{ Variable } & $\begin{array}{c}\text { Seropositive } \\
\quad \mathbf{n}=\mathbf{8 2}\end{array}$ & $\begin{array}{c}\text { Seronegative } \\
\mathrm{n}=\mathbf{2 3 9} \\
\end{array}$ & \multirow{2}{*}{$\begin{array}{l}\text { Crude } \\
\text { OR }^{\mathrm{a}}\end{array}$} & \multirow[t]{2}{*}{$95 \% \mathrm{Cl}^{\mathrm{b}}$} & \multirow[t]{2}{*}{$P$ value $^{e}$} \\
\hline & Freq. (\%) & Freq. (\%) & & & \\
\hline \multicolumn{6}{|l|}{ Socio-demographic Factors } \\
\hline Age (year) & $37.6(10.57)^{*}$ & $41.7(9.99)^{*}$ & 0.96 & $0.94,0.99$ & 0.002 \\
\hline Gender (Male) ${ }^{a}$ & $77(93.9)$ & $32(97.1)$ & 0.47 & $0.14,1.51$ & 0.202 \\
\hline Marital status (Single/Widower) ${ }^{b}$ & $21(25.6)$ & $32(13.4)$ & 2.23 & $1.20,4.14$ & 0.011 \\
\hline No of children & $3.5(2.36)^{*}$ & $3.7(2.53)^{*}$ & 0.96 & $0.85,1.07$ & 0.454 \\
\hline Income (RM) & $1115(375)^{*}$ & $1226(430)^{*}$ & 0.99 & $0.99,1.00$ & 0.041 \\
\hline Level of education ( $\geq$ Upper secondary) ${ }^{c}$ & $45(54.9)$ & $120(50.2)$ & 1.21 & $0.73,1.99$ & 0.466 \\
\hline \multicolumn{6}{|l|}{ Occupational Factors } \\
\hline Duration of employment (year) & $10.0(8.24)^{*}$ & $12.8(9.97)^{*}$ & 0.97 & $0.94,0.99$ & 0.026 \\
\hline Average work per week ( 6 or 7 days) ${ }^{d}$ & $43(52.4)$ & $87(36.4)$ & 1.93 & $1.16,3.20$ & 0.011 \\
\hline \multicolumn{6}{|l|}{ PPE used during work (yes) ${ }^{e}$} \\
\hline Boots & $33(40.2)$ & $147(61.5)$ & 0.42 & $0.25,0.70$ & 0.001 \\
\hline Long sleeve shirt & $66(80.5)$ & $194(81.2)$ & 0.96 & $0.51,1.81$ & 0.892 \\
\hline Rubber gloves & $28(34.1)$ & $76(31.8)$ & 1.11 & $0.65,1.89$ & 0.695 \\
\hline Mask & $8(9.8)$ & $49(20.5)$ & 0.42 & $0.19,0.93$ & 0.032 \\
\hline
\end{tabular}




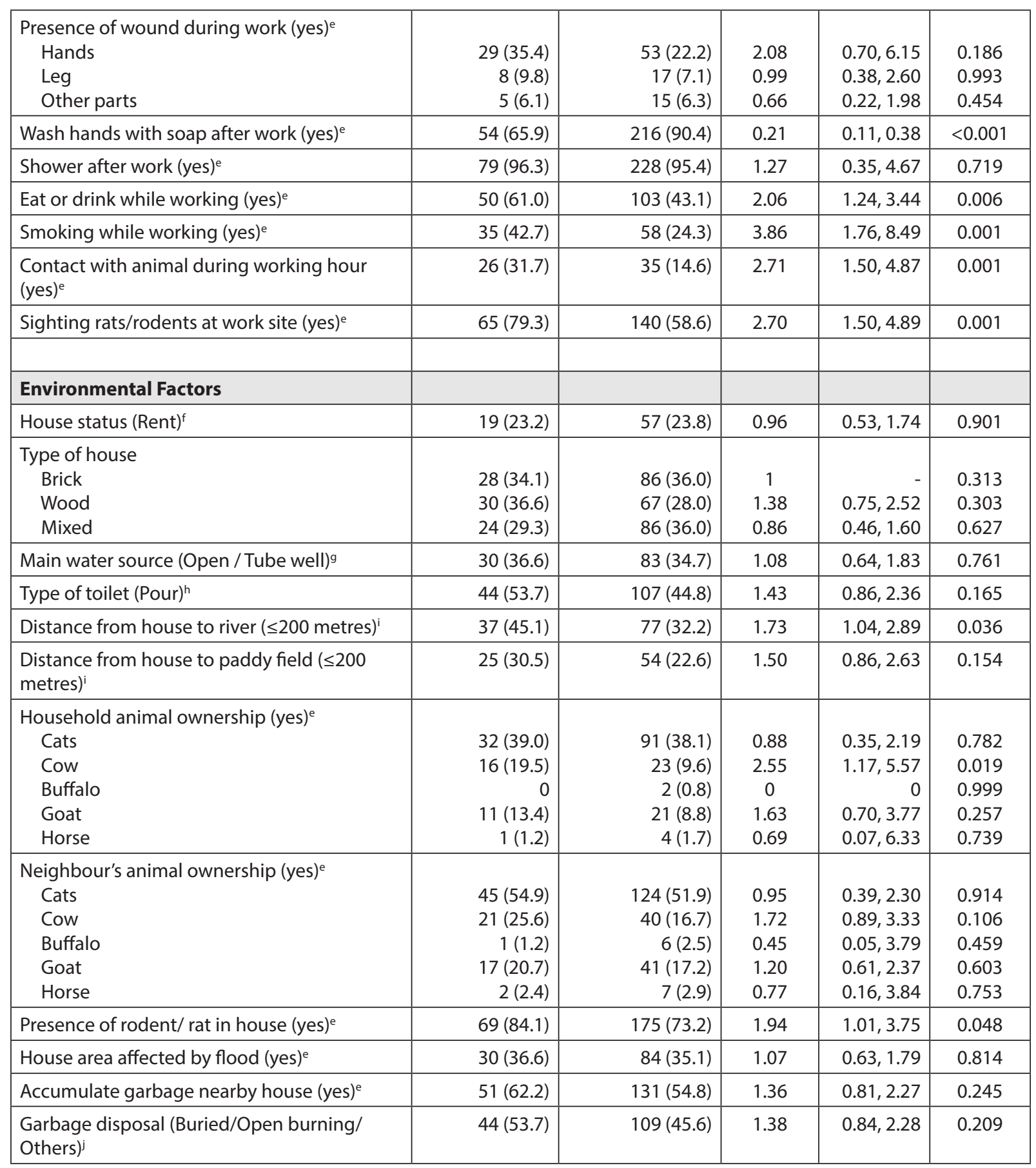

Reference group; afemale, ${ }^{b}$ married, clower secondary, d'work 5 days per week, eno, fowned, atreated pipe water, ${ }^{h}$ flush, i> 200meters, 'jpublic service, ${ }^{\mathrm{k}}$ satisfactory ( $\left.\geq 75 \%\right)$

$\mathrm{OR}=$ Odds ratio, $\mathrm{Cl}=$ Confidence Interval, $\mathrm{RM}=$ Ringgit Malaysia, $\mathrm{PPE}=$ Personal Protective Equipment

*Mean (SD) 
Table 2 cont.

\begin{tabular}{|c|c|c|c|c|c|}
\hline \multirow[t]{2}{*}{ Variable } & $\begin{array}{l}\text { Seropositive } \\
\quad n=82\end{array}$ & $\begin{array}{c}\text { Seronegative } \\
n=239\end{array}$ & \multirow[t]{2}{*}{$\begin{array}{c}\text { Crude } \\
\text { OR }^{\mathrm{a}}\end{array}$} & \multirow[t]{2}{*}{$95 \% \mathrm{Cl}^{\mathrm{b}}$} & \multirow[t]{2}{*}{ P value } \\
\hline & Freq. (\%) & Freq. (\%) & & & \\
\hline \multicolumn{6}{|l|}{ Recreational activities (yes) } \\
\hline Canoeing & $1(1.2)$ & $9(3.8)$ & 0.32 & $0.04,2.53$ & 0.277 \\
\hline Camping & $7(8.5)$ & $10(4.2)$ & 2.14 & $0.79,5.81$ & 0.137 \\
\hline Horse riding & $6(7.3)$ & $8(3.3)$ & 2.28 & $0.77,6.78$ & 0.138 \\
\hline Gardening & $43(52.4)$ & $122(51.0)$ & 1.06 & $0.64,1.75$ & 0.828 \\
\hline Swimming & $6(7.3)$ & $21(8.8)$ & 0.82 & $0.32,2.11$ & 0.680 \\
\hline Fishing & $29(35.4)$ & $68(28.5)$ & 1.38 & $0.81,2.34$ & 0.240 \\
\hline \multicolumn{6}{|l|}{ Worker's knowledge, attitude and practice } \\
\hline $\begin{array}{l}\text { Worker's knowledge } \\
\text { Good }(\geq 72 \%) \\
\text { Moderate }(<72 \%) \\
\text { Poor (Never heard) }\end{array}$ & $\begin{array}{l}20(24.4) \\
49(59.8) \\
13(15.9) \\
\end{array}$ & $\begin{array}{r}86(36.0) \\
112(46.9) \\
41(17.2) \\
\end{array}$ & $\begin{array}{c}1 \\
1.88 \\
1.36 \\
\end{array}$ & $\begin{array}{r}- \\
1.04,3.40 \\
0.62,3.01 \\
\end{array}$ & $\begin{array}{l}0.105 \\
0.036 \\
0.443 \\
\end{array}$ \\
\hline Worker's attitude (Unsatisfactory $(<75 \%))^{\mathrm{k}}$ & $47(57.3)$ & $107(44.8)$ & 1.66 & $0.99,2.75$ & 0.051 \\
\hline Worker's practice (Unsatisfactory $(<75 \%))^{\mathrm{k}}$ & $61(74.4)$ & $132(55.2)$ & 2.36 & $1.35,4.11$ & 0.003 \\
\hline
\end{tabular}

Reference group; afemale, ${ }^{b}$ married, clower secondary, ${ }^{d}$ work 5 days per week, eno, fowned, 9treated pipe water, hflush,



$\mathrm{OR}=$ Odds ratio, $\mathrm{Cl}=$ Confidence Interval, $\mathrm{RM}=$ Ringgit Malaysia, $\mathrm{PPE}=$ Personal Protective Equipment

${ }^{*}$ Mean (SD)

As shown in Table 3, there were seven associated risk factors for leptospiral infection, including working overtime, contact with animals while working, sighting of rats at the worksite and living $\leq 200 \mathrm{~m}$ from a river. Older age, wearing boots while working and washing hands with soap after work were identified as protective factors for leptospirosis. It was found that recreational activities and workers' knowledge, attitudes and practices were not significantly associated with leptospirosis.

Table 3 Associated factors for seropositive leptospirosis among 321 town service workers using multiple logistic regression

\begin{tabular}{|l|c|c|c|}
\hline Variable & $\begin{array}{c}\text { Adjusted } \\
\text { OR }^{\mathbf{a}}\end{array}$ & $\mathbf{9 5 \%} \mathbf{C l}^{\mathbf{b}}$ & $\boldsymbol{p}$-value \\
\hline Age (year) & 0.95 & $0.93,0.98$ & 0.001 \\
\hline $\begin{array}{l}\text { Working overtime } \\
\text { during the } \\
\text { weekend } \\
\text { No } \\
\text { Yes }\end{array}$ & \begin{tabular}{c}
1 \\
\hline es
\end{tabular} & $1.13,3.84$ & 0.011 \\
\hline
\end{tabular}

\begin{tabular}{|c|c|c|c|}
\hline $\begin{array}{l}\text { Wearing boots } \\
\text { during work } \\
\text { No } \\
\text { Yes }\end{array}$ & $\begin{array}{c}1 \\
0.44\end{array}$ & $0.25,0.80$ & 0.007 \\
\hline $\begin{array}{l}\text { Wash hands with } \\
\text { soap after work } \\
\text { No } \\
\text { Yes }\end{array}$ & $\begin{array}{c}1 \\
0.20\end{array}$ & $0.10,0.42$ & $<0.001$ \\
\hline $\begin{array}{l}\text { Contact with } \\
\text { animals during } \\
\text { working hours } \\
\text { No } \\
\text { Yes }\end{array}$ & $\begin{array}{c}1 \\
2.09\end{array}$ & $1.06,4.11$ & 0.033 \\
\hline $\begin{array}{l}\text { Sighting rats/ } \\
\text { rodents at the } \\
\text { worksite } \\
\text { No } \\
\text { Yes }\end{array}$ & $\begin{array}{c}1 \\
2.17\end{array}$ & $1.11,4.25$ & 0.024 \\
\hline $\begin{array}{l}\leq 200 \text { metres from } \\
\text { the house to the } \\
\text { river } \\
\text { No } \\
\text { Yes }\end{array}$ & $\begin{array}{c}1 \\
1.84\end{array}$ & $1.03,3.28$ & 0.039 \\
\hline
\end{tabular}

${ }^{\mathrm{a}} \mathrm{OR}=$ Odds Ratio, ${ }^{\mathrm{b}} \mathrm{Cl}=$ Confidence Interval Hosmer and Lemeshow Test $p$-value $=0.830$ Classification table overall percentage correct $=79.4 \%$ Area under ROC curve $=78.3 \%$ No multicollinearity 


\section{DISCUSSION}

Inthisstudy,agewastheonlysocio-demographic factor associated with seropositive leptospirosis and the only independent numerical variable associated with leptospiral infection. The mean age of the respondents was 40.6 (10.28) years, with a range of $20-68$ years. Interestingly, multiple logistic regression analyses showed that an increase in age of one year resulted in a 0.95 odds reduction of being seropositive for leptospirosis. A possible explanation is that as workers get older, they become more familiar with safe practices, within and outside of work. Workers were found to gain such knowledge through formal and informal education from employers, supervisors, friends or other sources, thus increasing their awareness of the health risks imposed by their daily work and personal activities. A similar finding is also reported by a study conducted in the Federated States of Micronesia (Colt et al., 2014).

In contrast, a cross-sectional study with 280 respondents from a rural area in Khuzestan, southwest Iran, reported that age was significantly associated with leptospiral infection. A higher infection rate was observed in those older than 35 years. The author mentioned that it was a well-known fact that young people in most of the villages in the region were not interested in doing outdoor work. They instead preferred to migrate in search of indoor work in big cities (Alavi et al., 2014). In another study, patients over 30 years old were found to have twice the risk of becoming a confirmed leptospirosis case compared to those aged $\leq 30$ years (Adj. OR: 2.16; 95\% Cl: 1.05, 4.41) (Vanasco et al., 2008). Nonetheless, this was laboratorybased surveillance of suspected leptospirosis cases and not a study among asymptomatic respondents in the occupational risk group.

Despite age not being a significant factor, leptospirosis has been found to occur mainly in younger age groups in several studies. A study conducted in southern India discovered that the majority of cases were found in people aged $21-30$ and $41-50$ years, which is also known as the productive age group. Thus, acquiring an infection during this period could result in a momentous economic impact on the family (Kamath et al., 2014). Another study in Laos revealed that the seroprevalence of leptospirosis among younger people (15-34 years) was higher than that in older age groups (35-78 years). The seroprevalence ranged from $23.9 \%$ to $30.6 \%$ in the younger age group, while in the older age group, it ranged from $18.6 \%$ to $24.7 \%$ (Kawaguchi et al., 2008).

Furthermore, studies in Thailand (Phraisuwan et al., 2002) and Mexico (LealCastellanos et al., 2003) reported that age was not a significant factor for leptospirosis seroprevalence and that seropositivity was not seen in certain younger or older age groups. Additionally, in a study with elderly people (aged $\geq 60$ years, and ranging from 60 to 78 years), leptospirosis was found to be associated with a severe course and higher risk for death, especially in those with an underlying comorbidity (Gancheva, 2013).

In the present study, five occupational factors were associated with leptospirosis exposure. Three were risk factors (i.e., working overtime, contact with animals while working and sighting rats at the worksite), whereas two were protective factors (i.e., wearing boots during work and washing hands with soap after working).

A normal work schedule involves working five days a week. However, to meet the demand for various services and minimise disruption to scheduled services, workers were offered additional work (i.e., overtime) at both regular and irregular hours. In this study, about $41 \%$ of the respondents chose to work overtime over the weekend. Those who work overtime have greater exposure to and more contact with water and soil that is possibly contaminated with leptospiral-infected urine compared to those who work five days a week. 
This is supported by the findings of the present study: those who worked overtime during the weekend had 2.13 times the odds of having leptospirosis compared to those who did not do overtime work during the weekend (Adj. OR: $2.13 ; 95 \% \mathrm{Cl}: 1.19,3.84 ; \mathrm{p}=0.011$ ).

There are many reports in the literature of prolonged exposure to and close contact with leptospiral-contaminated environments leading to an increased risk of leptospirosis (Hoenigl et al., 2014). For instance, in a study conducted in the Indian city of Surat, the risk of leptospirosis occurrence was 2.64 times higher among those who spent more than four days cleaning up after a flood than those who spent three days or less (Adj. OR $=2.64 ; 95 \%$ Cl: 1.18 - 5.89; $p<0.05$ ) (Bhardwaj et al., 2008). Another study conducted among adventure race participants in Florida, USA, reported that prolonged water exposure during the race was associated with an increased risk of leptospirosis (Stern et al., 2010). Prior to that, a study with Peruvian military members found that the leptospirosis infection rate was higher among recruits who stayed longer at the training site than among those who stayed for less time (Russell et al., 2003).

Wearing boots while working was identified as an independent protective predictor at the multivariable analysis level in the present study. Workers who practised wearing boots while working were less likely to have a leptospiral infection compared to those who did not wear boots while working (Adj. OR: $0.44 ; 95 \% \mathrm{Cl} 0.25,0.80 ; \mathrm{p}=0.007)$. This finding emphasises the importance of compliance with personal protective equipment (PPE) rules among town service workers. Similar findings regarding the protective effect of wearing boots while working against leptospirosis have also been reported in other studies (Leal-Castellanos et al., 2003; Mohd Ridzuan et al., 2016; Sulong et al., 2011). However, a few studies have also reported no association between wearing boots and leptospirosis (Phraisuwan et al., 2002).
Other PPE usage while working, such as wearing a long-sleeved shirt, rubber gloves or mask, was not associated with leptospirosis seropositivity among the respondents in this study. This finding was similar to that of a study conducted among town service workers in northeastern Malaysia in 2008 (Sulong et al., 2011). Another study among abattoir workers in New Zealand also reported that wearing PPE (e.g., gloves, a facemask, safety/ normal glasses or a balaclava) was not protective against leptospiral infection (Dreyfus et al., 2015). In Thailand, it was also reported that the use of gloves and long-sleeved shirts was not associated with leptospirosis (Phraisuwan et al., 2002), while a population-based casecontrol study in Brazil revealed that the use of gloves while working was not a protective factor against leptospirosis (Sarkar et al., 2002).

Proper handwashing is an important preventive measure against leptospiral infection because it removes potentially contaminated water or soil from the hands. This is also consistent with the fact that the transmission of leptospirosis may occur through ingestion (WHO, 2003). In the present study, this factor was found to be protective against leptospiral infection, and this finding aligns with the results of a 2008 study among town service workers (Sulong et al., 2011). A cohort study conducted in Sweden with employees engaged in postflood management activities reported an association between neglecting handwashing after contact with floodwater/sediment and the risk of illness (Wojcik et al., 2013). However, this factor was not found to be significant in a study of 150 workers in a slaughterhouse in Brazil (Gonçalves et al., 2006).

Contact with secretions, blood or urine of animals while working, especially leptospireinfected reservoirs, might predispose workers to leptospirosis via a direct transmission (Bharti et al., 2003). In the present study, workers who had contact with animals while working had two times the odds of having 
leptospirosis compared to those who had no contact with animals while working (Adj. OR: 2.09; 95\% Cl: 1.06, 4.11; $p=0.033$ ). Those with reported animal contact stated rodents, cows, sheep and rabbits as examples of the common animals they had contact with while working. One respondent also stated that he had contact with a dog while working. These animals are known reservoirs for leptospires, and other studies have found that the odds of developing leptospirosis increase when there is contact with these animals. A study conducted in western Jamaica discovered that contact with rodents and goats increased the odds of leptospirosis by about four and three times, respectively (Keenan et al., 2010). Increased risk due to animal contact was also seen in studies in Iran (Alavi et al., 2014). In contrast, no association was found in some studies conducted in Malaysia (Sulong et al., 2011) and Brazil (Lacerda et al., 2008).

Rodents are important reservoir hosts for pathogenic serovars of Leptospira and are the most common source of human leptospirosis (Bharti et al., 2003). In the present study, a significant association was found between the sighting of rats or other rodents in the workplace and seropositivity for leptospirosis among town service workers. Those who had seen rats or other rodents at their worksite had two times the odds of being seropositive for leptospirosis compared to those who had not seen rats or rodents at their workplace (Adj. OR: $2.17 ; 95 \% \mathrm{Cl}: 1.11,4.25 ; \mathrm{p}=0.024)$. This might be due to the workers being in contact with rats; some were involved in pest control in areas with high rodent populations. A crosssectional study among butchers and their assistants in Jamaica also found that sighting live rodents in the slaughterhouse played a significant role in leptospirosis seropositivity among the respondents (Brown et al., 2011). This finding is in agreement with the results of a study conducted in Salvador, Brazil (Sarkar et al., 2002). Nonetheless, studies among highrisk occupational groups found no association between the sighting of rats or other rodents at the workplace and leptospirosis seropositivity (Sulong et al., 2011).
When environmental factors were taken into account, the present study revealed that residing near a river (within $200 \mathrm{~m}$ ) was a significant factor associated with leptospirosis. Workers who resided $\leq 200 \mathrm{~m}$ from a river had about two times the odds of being seropositive for leptospirosis compared to those who resided more than $200 \mathrm{~m}$ from a river (Adj. OR: $1.84 ; 95 \% \mathrm{Cl}: 1.03,3.28 ; \mathrm{p}=0.039$ ). Similar findings were reported in studies conducted in India (Philip et al., 2013) and in a previous study on leptospirosis among town service workers in Malaysia (Sulong et al., 2011). These findings suggest that the respondents were at higher odds of exposure to Leptospira if they were engaged in water-related activities or experienced flood-related problems near their houses. However, the finding contradicts other studies conducted around the world that reported no association between the distance of a house from a river and leptospirosis (Nardone et al., 2004).

Among the limitations of the present study is the fact that the job category was not considered an occupational factor. The number of respondents in the garbage collector job category was too small to permit a comprehensive assessment of the probable risk factor. Despite our effort to explain the importance and confidentiality of the study to the respondents during data collection and the support of the supervisors and heads of departments, it was noted that workers, especially from the garbage collector job category, refused to take part in the study due to personal reasons. As participation was voluntary and considering the need to comply with the ethical guidelines, we respected their decision not to join the study. A similar problem of small sample size in a certain job category also occurred in another study among town service workers; in that case, the researchers also did not analyse the association between the job category of the respondents and leptospirosis seropositivity (Sulong et al., 2011). 


\section{CONCLUSION}

Several demographic, occupational and environmental factors were found to be significantly associated with leptospirosis seropositivity among town service workers in northeastern Malaysia. In terms of occupational risk factors, those who did overtime work, had animal contact while working, sighted rats at the worksite and lived $\leq 200 \mathrm{~m}$ from a river were at high risk of leptospirosis infection. Thus, prevention and control strategies for leptospirosis will need to focus on possible sources of leptospirosis transmission and highrisk activities in the workplace.

\section{CONFLICT OF INTEREST}

The authors have no conflicts of interest to declare.

\section{ACKNOWLEDGEMENTS}

The authors would like to express our deepest gratitude and thanks to all respondents of the survey who provided us with their valuable responses in this study. The study was funded by the Universiti Sains Malaysia Research University Grant (No. 1001/PPSP/812131) and was ethically approved by the Research and Ethics Committee (Human) of Universiti Sains Malaysia.

Ethical clearance was obtained from the Research and Ethic Committee (Human), School of Medical Sciences, Health Campus, Universiti Sains Malaysia (Reference No: USMKK/PPP/JEPeM [261.3(7)]).

\section{REFERENCES}

Alavi, L., Alavi, S. M., \& Khoshkho, M. M. (2014). Risk Factors of Leptospirosis in Khuzestan, South West of Iran, 2012. Int J Entric Pathog, 1 (2), 68 - 71. https://doi.org/10.17795/ ijep15248

Bhardwaj, P., Kosambiya, J. K., \& Desai, V. K. (2008). A case control study to explore the risk factors for acquisition of leptospirosis in Surat city, after flood. Indian Journal of Medical Sciences, 62 (11), 431 - 438. https://doi. org/10.4103/0019-5359.48454
Bharti, A. R., Nally, J. E., Ricaldi, J. N., Matthias, M. A., Diaz, M. M., Lovett, M. A., Levett, P. N., Gilman, R. H., Willig, M. R., Gotuzzo, E., \& Vinetz, J. M. (2003). Leptospirosis: A zoonotic disease of global importance. The Lancet Infectious Diseases, 3 (12), 757 - 771. https:// doi.org/10.1016/S1473-3099(03)00830-2

Brown, P. D., McKenzie, M., Pinnock, M., \& McGrowder, D. (2011). Environmental risk factors associated with leptospirosis among butchers and their associates in Jamaica. International Journal of Occupational \& Environmental Medicine, 2 (1), 47 - 57.

Cointreau, S. (2006). Occupational and environmental health issues of solid waste management: special emphasis on middleand lower-income countries. In The World Bank Group Washington, D.C.

Colt, S., Pavlin, B. I., Kool, J. L., Johnson, E., McCool, J. P., \& Woodward, A. J. (2014). Human leptospirosis in The Federated States of Micronesia: A hospital-based febrile illness survey. BMC Infectious Diseases, 14 (1), 186. https://doi.org/10.1186/1471-2334-14-186

Dircio Montes Sergio, A., González Figueroa, E., María Saadia, V. G., Elizabeth, S. H., Beatriz, R. S., Altuzar Aguilar Víctor, M., \& Navarrete Espinosa, J. (2012). Leptospirosis Prevalence in Patients with Initial Diagnosis of Dengue. Journal of Tropical Medicine, 2012, 1 - 5. https://doi.org/10.1155/2012/519701

Dreyfus, A., Wilson, P., Collins-Emerson, J., Benschop, J., Moore, S., \& Heuer, C. (2015). Risk factors for new infection with Leptospira in meat workers in New Zealand. Occupational and Environmental Medicine, 72 (3), 219 - 225. https://doi.org/10.1136/ oemed-2014-102457

Gancheva, G. I. (2013). Leptospirosis in elderly patients. The Brazilian Journal of Infectious Diseases, 17 (5), 592 - 595. https://doi. org/10.1016/j.bjid.2013.01.012

Gonçalves, D. D., Teles, P. S., Reis, C. R. dos, Lopes, F. M. R., Freire, R. L., Navarro, I. T., Alves, L. A., Muller, E. E., \& Freitas, J. C. de. (2006). Seroepidemiology and occupational and environmental variables for leptospirosis, brucellosis and toxoplasmosis in slaughterhouse workers in the Paraná State, Brazil.RevistaDolnstituto deMedicina Tropical de São Paulo, 48 (3), 135 - 140. https://doi. org/10.1590/S0036-46652006000300004

Hoenigl, M., Wallner, C., Allerberger, F., Schmoll, F., Seeber, K., Wagner, J., Valentin, T., ZollnerSchwetz, I., Flick, H., \& Krause, R. (2014). Autochthonous Leptospirosis in South-East Austria, 2004 - 2012. PloS One, 9 (1), e85974. https://doi.org/10.1371/journal.pone.0085974 
Kamath, R., Swain, S., Pattanshetty, S., \& Nair, N. S. (2014). Studying risk factors associated with Human Leptospirosis. Journal of Global Infectious Diseases, 6 (1), 3. https://doi. org/10.4103/0974-777X.127941

Kawaguchi, L., Sengkeopraseuth, B., Tsuyuoka, R., Koizumi, N., Akashi, H., Vongphrachanh, P., Watanabe, H., \& Aoyama, A. (2008). Seroprevalence of leptospirosis and risk factor analysis in flood-prone rural areas in Lao PDR. Am J Trop Med Hyg, 78 (6), 957 - 961. https://doi.org/10.4269/ajtmh.2008.78.957

Keenan, J., Ervin, G., Aung, M., McGwin Jr, G., \& Jolly, P. (2010). Risk factors for clinical leptospirosis from Western Jamaica. The American Journal of Tropical Medicine and Hygiene, 83 (3), 633. https://doi.org/10.4269/ajtmh.2010.09-0609

Lacerda, H. G., Monteiro, G. R., Oliveira, C. C. G., Suassuna, F. B., Queiroz, J. W., Barbosa, J. D. A., Martins, D. R., Reis, M. G., Ko, A. I., \& Jeronimo, S. M. B. (2008). Leptospirosis in a subsistence farming community in Brazil. Transactions of the Royal Society of Tropical Medicine and Hygiene, 102 (12), 1233 - 1238. https://doi. org/10.1016/j.trstmh.2008.05.010

Leal-Castellanos, C. B., Garcia-Suarez, R., Gonzalez-Figueroa, E., Fuentes-Allen, J. L., \& Escobedo-De La Pena, J. (2003). Risk factors and the prevalence of leptospirosis infection in a rural community of Chiapas, Mexico. Epidemiology and Infection, 131 (3), 1149 - 1156. https://doi.org/10.1017/ S0950268803001201

Levett, P. N. (2001). Leptospirosis. Clin Microbiol Rev, 14 (2), 296 - 326. https://doi.org/10.1128/ CMR.14.2.296-326.2001

Ministry of Health, M. (2011). Guidelines For The Diagnosis, Management, Prevention and Control of Leptospirosis in Malaysia. http:// moh.gov.my/images/gallery/Garispanduan/ GL_Leptospirosis 2011.pdf

MohdRidzuan, J., Aziah, B. D., \& Zahiruddin, W. M. (2016). The occupational hazard study for leptospirosis among agriculture workers. Int. J. Collab. Res. Intern. Med. Public Health, 8, $284-293$.

Nardone, A., Capek, I., Baranton, G., Campèse, C., Postic, D., Vaillant, V., Lié, M., \& Desenclos, J.-C. (2004). Risk factors for leptospirosis in metropolitan France: results of a national case-control study, 1999-2000. Clinical Infectious Diseases, 39 (5), 751 - 753. https:// doi.org/10.1086/423272

Philip, R. R., PS, I., \& Joy, T. M. (2013). Occupational and environmental risk factors of Leptospirosis: A case control study in a tertiary care setting in Kerala, India. Health Sciences, 2 (1), 1 - 12.
Phraisuwan, P., Whitney, E. A., Tharmaphornpilas, P., Guharat, S., Thongkamsamut, S., Aresagig, S., Liangphongphanthu, J., Junthima, K., Sokampang, A., \& Ashford, D. A. (2002). Leptospirosis: skin wounds and control strategies, Thailand, 1999. Emerging Infectious Diseases, 8 (12), 1455 - 1459. https://doi.org/10.3201/eid0812.020180

Plank, R., \& Dean, D. (2000). Overview of the epidemiology, microbiology, and pathogenesis of Leptospira spp. in humans. Microbes and Infection, 2 (10), 1265 $1276 . \quad$ https://doi.org/10.1016/S12864579(00)01280-6

Russell, K. L., Gonzalez, M. A. M., Watts, D. M., Lagos-Figueroa, R. C., Chauca, G., Ore, M., Gonzalez, J. E., Moron, C., Tesh, R. B., \& Vinetz, J. M. (2003). An outbreak of leptospirosis among Peruvian military recruits. American Journal of Tropical Medicine and Hygiene, 69 (1), 53 - 57. https://doi.org/10.4269/ ajtmh.2003.69.53

Sarkar, U., Nascimento, S. F., Barbosa, R., Martins, R., Nuevo, H., Kalofonos, I., Kalafanos, I., Grunstein, I., Flannery, B., \& Dias, J. (2002). Population-based case-control investigation of risk factors for leptospirosis during an urban epidemic. The American Journal of Tropical Medicine and Hygiene, 66 (5), 605 - 610. https://doi.org/10.4269/ ajtmh.2002.66.605

Spies, S. (2010). Health Risks Related to Solid Waste Management. Solid Waste Management in the World's Cities: Water and Sanitation in the World's Cities 2010. Earthscan. pp. 14 - 18.

Stern, E. J., Galloway, R., Shadomy, S. V, Wannemuehler, K., Atrubin, D., Blackmore, C., Wofford, T., Wilkins, P. P., Ari, M. D., \& Harris, L. (2010). Outbreak of leptospirosis among Adventure Race participants in Florida, 2005. Clinical Infectious Diseases, 50 (6), 843 - 849. https://doi.org/10.1086/650578

Sulong, M. R., Shafei, M. N., Yaacob, N. A., Hassan, H., Daud, A., Wan Mohamad, W. M. Z., Ismail, Z., \& Abdullah, M. R. (2011). Risk factors associated with leptospirosis among town service workers. International Medical Journal, 18 (2), 83 - 88.

Thayaparan, S., Robertson, I., Fairuz, A., Suut, L., \& Abdullah, M. (2013). Leptospirosis, an emerging zoonotic disease in Malaysia. The Malaysian Journal of Pathology, 35 (2), 123 132. 
Vanasco, N. B., Schmeling, M. F., Lottersberger, J., Costa, F., Ko, A. I., \& Tarabla, H. D. (2008). Clinical characteristics and risk factors of human leptospirosis in Argentina (1999 2005). Acta Tropica, 107 (3), 255 - 258. https:// doi.org/10.1016/j.actatropica.2008.06.007

Victoriano, A., Smythe, L., Gloriani-Barzaga, N., Cavinta, L., Kasai, T., Limpakarnjanarat, K., Ong, B., Gongal, G., Hall, J., Coulombe, C., Yanagihara, Y., Yoshida, S., \& Adler, B. (2009). Leptospirosis in the Asia Pacific region. BMC Infectious Diseases, 9 (1), 147. https://doi. org/10.1186/1471-2334-9-147

WHO. (2003). Human Leptospirosis: Guidance For Diagnosis, Surveillance and Control. https:// apps.who.int/iris/handle/10665/42667
WHO.(2007).Leptospirosis LaboratoryManual.https:// apps.who.int/iris/handle/10665/205429

Wojcik, O. P., Holt, J., Kjerulf, A., Müller, L., Ethelberg, S., \& Mølbak, K. (2013). Personal protective equipment, hygiene behaviours and occupational risk of illness after July 2011 flood in Copenhagen, Denmark. Epidemiology and Infection, 141 (8), 1756 - 1763. https://doi.org/10.1017/ S0950268812002038

Zavitsanou, A., \&Babatsikou, F. (2008). Leptospirosis: epidemiology and preventive measures. Health Science Journal, 2 (2), 75 - 82. 